\title{
The Effects of Doing More with Less in the Public Sector: \\ Evidence from a Large-Scale Survey
}

\author{
Marc Esteve (University College London) \\ Christian Schuster (University College London) \\ Adria Albareda (Leiden University) \\ Carlos Losada (ESADE Business School)
}

\begin{abstract}
Since the onset of the Great Recession, "doing more with less" has become a policy mantra. To do more with less, a range of governments have concurrently imposed wage cuts and greater work demands on public employees. This article assesses the impact of these changes on the job satisfaction and work motivation of public employees in 34 European countries. Congruent with previous studies linking income and working hours with job attitudes, it finds a negative impact on both. There are thus no free austerity lunches: while public employees may work longer hours at lower pay, they are less satisfied and less motivated when doing so. One caveat applies. The effect on motivation - albeit not satisfaction - is mitigated when employees feel their values are aligned with those of their organizations. This puts a premium on public managers fostering value alignment, particularly when it is hardest to achieve: in times of cutbacks.
\end{abstract}

Forthcoming in Public Administration Review 


\section{Introduction}

In the last decade, public organizations across the globe have been put under stress by increasingly demanding work environments. This trend is driven by the concurrence of austerity measures and greater citizen demands for quality public services (Karanikolos et al. 2013: Raudla et al. 2015). In other words, since the Great Recession, public employees have been asked to do more with less. This trend continues unabated in many countries, with ongoing spending cuts in public sectors from Brazil to Greece to several U.S. states, to name just a few. As a result, delivering improved services through a motivated workforce has become "one of the main challenges for the public sector in the developed world" (Leslie and Canwell 2010, 297). Concurrently, the relationship between austerity, enhanced work demands and organizational behavior has become of central importance to public sector governance.

Yet, this relationship remains underexplored in the post Great-Recession period. This is even though austerity and cutbacks have been rediscovered as a research topic by public management scholars since the onset of the financial and economic crises in 2008 (see, among many, Bozeman 2010; Pandey 2010; Lodge and Hood 2012). These studies build on earlier, seminal work on public management challenges during recessions (Levine 1979). A subset of these studies has hinted qualitatively at potential adverse impacts of "salami slicing" and other cutback strategies on bureaucratic behavior and attitudes (Hood 2010). Cutbacks are, to cite just one mechanism, argued to undermine the social contract in public organizations - which is partially based on predictability in benefits and pay. As such, they are argued to "pose a direct challenge to employee motivation" (Pandey 2010, 567). Practitioners echo this concern, fearing a "negative impact on the morale of staff" (OECD 2012, 
36). At the same time, however, from an empirical perspective the "effects of salary cutbacks and freezes on staff motivation are not clear" (OECD 2012, 37).

This is an important omission. Great Recession and post-Great Recession cutbacks across the globe can be expected to shape public employees' attitudes and behavior: they directly affect livelihoods and work lives of public employees. Cutbacks tend to do so as because "the public wage bill is typically a major target during fiscal consolidations," as, "especially during crises, many other expenditure items are difficult to cut quickly" (Forni and Novta 2014, 3). In fact, 20 OECD member countries imposed wage cuts in the public sector since 2009; and an additional 15 countries implemented staff reduction programs (OECD 2012). Arguably, it seems that public employees are thus paid less to do more with less staff.

Whether they, in fact, do more with less while being paid less remains in part unclear, however. To our knowledge, four studies have assessed the impact of post-2009 cutbacks on work-related attitudes, well-being and behavior of public sector staff (Conway et al. 2014; Kiefer et al. 2015; van der Voet and Van de Walle 2015; van der Voet and Vermeeren 2016). Except for van der Voet and Van de Walle, (2015) who do not identify significant average effects, they associate cutbacks with lower job satisfaction, employee well-being, organizational commitment and citizenship behavior.

While these results are a helpful starting point for the present article, they paint an incomplete picture of the effects of Great Recession and post-Great Recession austerity measures in public sectors. None of the studies assesses the effect of salary changes on bureaucratic attitudes and behavior - even though wage cuts have constituted the most widespread cutback since 2009 (OECD 2012). All focus 
exclusively or largely on public managers - rather than lower-level employees who are typically the target of cutbacks. And none has focused explicitly on work motivation - despite its centrality in achieving more with less.

This article fills these lacunae by answering a central research question in austerity governance: what are the net effects of wage cuts and enhanced work demands on work motivation and job satisfaction of public employees? We address this question for 34 European countries -thus shedding the most comprehensive empirical light on the effects of the Great Recession in public sectors to-date.

\section{Literature and theory}

Job satisfaction and work motivation have been a staple of scholarly research on the public sector. An exhaustive review would exceed the scope of this article. Job satisfaction in the public sector alone, for instance, has seen at least 99 studies that identified 43 potential correlates (Cantarelli, Belardinelli, and Belle 2015). Hence, our ambition is more modest: to review studies shedding theoretical or empirical light on the effects of two key variables in austerity governance - income and working hours on, first, job satisfaction and, second, work motivation. Subsequently, we will consider how values and value alignment may shape these effects.

In the case of job satisfaction, a significant body of literature argues that income and working hours are strong predictors of job satisfaction (Nanda and Browne 1977; Clark and Oswald 1996; Baltes et al. 1999; Judge et al. 2010). Both social exchange theory and job demands-resources theory provide theoretical rationales for this finding. 
According to social exchange theory, employees evaluate the fairness of their working conditions by "comparing their own ratio of inputs (e.g., effort and skill) and outcomes (pay, recognition) to the input-outcome ratios of important 'comparison others' such as close coworkers, workers in other companies, or the employee's past work history" (Rynes, Gerhart, and Minette 2004, 388). Consequently, where employees compare their current situation - lower pay and/or longer working hours with their own past in times of cutbacks, their notion of equity is violated. Rousseau (2001) states that this violation in turn constitutes a breach of contract between the employee and the organization. Rousseau's theory - which derives from social exchange theory - is based on the notion of an unwritten agreement (a psychological contract) between employees and their organization: employees expect to perform certain tasks to obtain certain rewards. Greater predictability of pay and benefits in the public sector, arguably, enhance the perceived strength and importance of this contract in the case of public employees. Cutbacks thus breach both this psychological contract and employee notions of equity. Consequently, employee satisfaction with their jobs declines.

Job-demands theory provides an alternative theoretical account to explain the negative relationship between cutbacks and job satisfaction (Bakker and Demerouti 2007). Cutbacks concurrently enhance work demands and decrease the amount of resources employees can rely on in their work. They may thus exhaust employees' mental and physical resources, resulting in decreased job engagement and satisfaction.

Theoretically, we may thus expect a significant negative relationship between worse working conditions and job satisfaction. Empirically, the relationship between income 
and working hours and job satisfaction has been recurrently explored. In the public sector, a recent meta-analysis has identified sixteen studies linking income with job satisfaction, yielding on average a moderate positive correlation between the two. Similarly, fewer work demands are positively and moderately correlated with job satisfaction, albeit with a smaller number of studies and observations supporting this inference (Cantarelli, Belardinelli, and Belle 2015). The select prior research more specifically focused on the attitudinal effects of the Great Recession in the public sector is, as noted in the introduction, largely congruent with this prediction: it associates cutbacks with lower job satisfaction (Conway et al. 2014; Kiefer et al. 2015; van der Voet and Vermeeren 2016). With the findings of these studies in mind, it is plausible to hypothesize that wage cuts and enhanced work demands on public employees in Europe - in short worse working conditions - impact their attitudes towards their jobs and, in particular, job satisfaction in the following way (H1):

Hypothesis 1: Worse working conditions contribute to lower levels of job satisfaction of public employees.

Next to job satisfaction, prior studies point to a plausible effect of working conditions on work motivation. We understand work motivation here as an inner force that drives individuals to accomplish specific tasks that are believed to have a positive effect towards the organization's performance (Perry and Porter 1982). Thus, it gives individuals' behavior purpose, persistence and direction.

In the general management literature, salary changes and working overtime have been found to be strong predictors of work motivation (Beckers et al. 2004; Frey 1997; Rynes, Gerhart, and Minette 2004). When companies cut salaries of employees and ask them to keep working the same number of hours, their motivation diminishes. As 
with job satisfaction, social exchange - and its derivative psychological contract theory provides a theoretical rationale for this negative effect of (worse) working conditions on motivation. As noted above, cutbacks breach both the employees' psychological contract with their employer and employee notions of equity, including by reducing advancement opportunities, compensation and job security. In response to reduced efforts from the organization, employees reduce their contributions to the organization - and thus rebalance the exchange relationship - by decreasing their effort and investment toward the organization (Lavelle, Rupp, and Brockner 2007).

Whether this theoretical prediction does lead to lower motivation of employees in public sector contexts remains empirically scarcely tested, however. Public service motivation (PSM) has been extensively researched (Perry, Hondeghem, and Wise 2010). For our purposes, however, PSM is of limited use. It is a more circumscribed concept, referring to motives that drive individuals to help society and its citizens (Kim and Vandenabeele 2010; Perry and Wise 1990) - rather than a broader motivation to accomplish tasks that are perceived to benefit an organization's performance.

Similarly, in regards to the effect of pay, the relationship between pay-forperformance on public employee motivation has seen ample studies; a recent metaanalysis includes 46 such studies (Weibel, Rost, and Osterloh 2010). Yet, the effect of pay cuts and increases in working hours on work motivation is much less wellexplored. Resource reductions have been associated with lower morale in the public sector qualitatively, but not quantitatively (Levine 1979; Kiefer et al. 2015; Lindorff, Worral, and Cooper 2011). Our study improves upon this limited quantitative 
evidence basis, testing whether the motivation of public employees asked to earn less and/or work longer hours for the same salary decreases $(\mathrm{H} 2)$.

Hypothesis 2: Worse working conditions contribute to lower levels of work motivation of public employees.

Salary cuts and increased working hours are not the only determinants of job attitudes such as job satisfaction or work motivation. Other variables are also at play. Importantly, these variables may mediate the effect of working conditions on job attitudes. To illustrate, in the post-2008 austerity context, van der Voet and Van de Walle (2015) identify a mediating role for autonomy when it comes to explaining job satisfaction. Our article accounts for this empirically and goes further from a theoretical point of view. It, additionally, considers the role of value alignment in job satisfaction and work motivation in the post-2008 austerity context.

As context for this discussion, note that values may be understood as "a broad tendency to prefer certain states of affairs over others" (Hofstede 1980, 19). Attitudes, by contrast, are "a relatively enduring organization of beliefs around an object or situation predisposing one to respond in some preferential manner" (Rokeach 1968, 112). The two are related but distinct: in Homer and Kahle's (1988) terms, values predict attitudes and attitudes predict behaviors. Drawing on job-demands and psychological contract theory, we argue that value alignment moderates the effect of working conditions on job satisfaction and work motivation.

Several prior studies of the determinants of job satisfaction have shown that the congruence between an individual's personal values and those reflected in the organization and individual's job is a significant predictor of job satisfaction (see, 
among others, Kirkman and Shapiro 2001). Extrapolating from job-demands theory provides a theoretical rationale for, additionally, expecting value alignment to moderate the effect of austerity-induced cutbacks on job satisfaction (H3). If employees develop job tasks that reflect - and enable them in their workplace to live by - their personal values, worse working conditions are less likely to exhaust employees' mental and physical resources, and thus decrease their job satisfaction. Empirically, H3 builds on prior studies which have found that value alignment does moderate the effect of worse working conditions on a related concept: employee wellbeing (Schaufeli 2015; Leiter, Frank, and Matheson 2009).

Hypothesis 3: Value alignment will moderate the negative effects of worse working conditions on job satisfaction.

A similar moderating effect may be expected in the case of work motivation. Motivation can be understood as an assumed mental program that is associated with both attitudes and values (Hofstede 1980) - or, in motivation terminology, expectancies and valances (see Vroom 1964). In fact, empirically, values - next to core personality traits and attitudes - have been identified as key antecedents of work motivation (van Witteloostuijn, Esteve, and Boyne 2017). Congruently, value alignment has been found to be a central predictor of performance - and motivation of employees and organizations (Brown 1976; Paarlberg and Perry 2007). In contrast, requests to act against what an employee "knows to be right" are major sources of conflict within organizations. Empirical implications of value alignment then include, for instance, employees working harder if they believe in the mission of the organization (Wright 2007). 
Extrapolating from psychological contract theory, we hypothesize that value alignment not only enhances employee work motivation, but also moderates the effects of working conditions. If employee values are aligned with those of the organization, the pursuit of organizational values - rather than pay and shorter working hours - becomes relatively more important in employees' psychological contracts with public organizations. As such, a change in organizational values rather than pay and working hours may constitute the major breach of contract for employees. At high levels of value alignment, worse working conditions may thus impair work motivation relatively less. This leads us to hypothesize (H4):

Hypothesis 4: Value alignment will moderate the negative effects of worse working conditions on work motivation.

If $\mathrm{H} 3$ and $\mathrm{H} 4$ were to be true, this would light a small beacon of hope for 'doing more with less' advocates. Public managers could salvage the job satisfaction and work motivation of their employees by ensuring high value alignment. At the same time, it would refine the scholarly understanding of job satisfaction and work motivation of public employees in times of austerity.

\section{Data and Methods}

The data for hypothesis testing is drawn from the fifth edition of the European Working Conditions Surveys (EWCS), conducted in 2010. In this edition, workers were surveyed in the EU28 plus Macedonia, Turkey, Norway, Albania, Kosovo, and Montenegro. The survey was implemented via face-to-face interviews by Gallup Europe and its network of national institutes (Gallup Europe, 2010). Interviews were conducted at the home of the interviewee and in the national language(s) of the 
country. Several duties of care enhance confidence in validity. Experts of Eurofound's European Working Conditions Observatory reviewed the quality of the translated questionnaires; interviewers did not carry out more than 20 interviews each, to mitigate possible biases from interviewer effects; and interviewers participated in detailed briefings developed by the national institutes of Gallup Europe.

\section{Sample}

The sample was selected by a multi-stage, stratified, random approach. A primary sampling unit was drawn randomly for each region of the 34 countries by considering the degree of urbanization. Secondly, a random sample of households was drawn in each primary sampling unit. Finally, the worker chosen in each household was the one who had his or her birthday next. Therefore, only one interview was conducted in each household. As Daniels (2004) writes, this sampling method produces samples representative of the wider working population (see also Paoli and Merllié 2001). Each participant country interviewed at least 1,000 employees (see Gallup Europe 2010 for the overall number of responses per country). Participants needed on average 42 minutes to complete the questionnaire. In total 43,816 employees were surveyed, at a response rate of $44.2 \%$. To classify respondents, the questionnaire asked each participant to select one of the following options: private sector; public sector; joint public-private organization or company; not-for-profit sector, NGO; Other (define), Do not know; and finally, refusal to answer the question. This article focuses on the 9,761 employees (i.e. excluding managers) who work in the public sector. ${ }^{1}$ The final sample contains employees from several sectors: central public administration (22\%), education $(29 \%)$ and health $(20 \%)$. 


\section{Dependent Variables}

The two dependent variables (i.e. job satisfaction and motivation) are based on a single item question. Job satisfaction is measured on a 4-point Likert scale with the question "On the whole, are you very satisfied, satisfied, not very satisfied or not at all satisfied with working conditions in your main paid job?" This type of single-item overall job satisfaction measure has been shown to be equally reliable and valid as multiple-item measures (Dolbier et al. 2004; Nagy 2002; Wanous, Reichers, and Hudy 1997). Work motivation is measured on a 5-point Likert scale with the question “The organization I work for motivates me to give my best job performance." Work motivation is thus understood in its broader sense as a force that drives individuals to accomplish personal and organizational goals.

Our two dependent variables are related but distinct concepts. Prior research suggests that they can mutually affect each other, but may still be present without the respective other (Furnham, 1992; Furnham et al. 2009). As such, it is important to study them as separate dependent variables. Our study is empirically congruent with this assertion: our two dependent variables are significantly, albeit not highly correlated $(\mathrm{r}=0.38)$.

\section{Explanatory Variables}

The key explanatory variables in the survey are questions querying about changes in income and working hours:

- "If you compare your current situation with that of January 2009, have you experienced a change in your salary or income?" 
- "If you compare your current situation with that of January 2009, have you experienced a change in the number of hours you work per week?"

They are measured on a 1-3 scale (1=Decrease; $2=$ No change; $3=$ Increase). Note that the period of change measured - 2009-2010 - coincides with the onset of austerity in a range of countries. In 2009-2010, 14 OECD countries sought fiscal consolidation measures (OECD 2012). To illustrate, these ranged from reduced base pay (e.g. Slovenia) to cuts in bonuses and allowances (e.g. Greece) to increased working hours (e.g. Spain and Portugal), among others (Forni and Novta 2014; OECD 2012).

By drawing on the 2010 survey, our study underestimates the effects of the Great Recession on public employees' job attitudes and behavior. The effects of further and more severe - fiscal retrenchment in 2011-2013 are not considered (Di Mascio and Natalini 2015). Note, however, that as a result the study's estimates are biased against our hypotheses. If the less severe austerity measures in 2009-2010 are found to influence public employees, we can expect more severe subsequent measures to affect public employees even more significantly. The empirical analysis below thus represents a particularly challenging - and robust - test of our hypotheses.

To estimate the behavioral effects of 'doing more with less', we aggregate the two questions about salaries and working hours into a single measure that captures austerity-induced changes in working conditions. This concept is measured on a scale ranging from 1 (working conditions have worsened) to 5 (working conditions have improved). More specifically, 1 indicates an increase in working hours and wage cut; 2 is an increase in working hours and no salary change, or no change in working hours and a pay cut; 3 indicates no change in either working hours or salary; 4 implies a decrease in working hours and no salary change, or no change in working hours and 
a salary increase; finally, 5 indicates a decrease in working hours and increase in salary. Note that, as a measure of retrospective reporting of pay and working hour changes by respondents, the measure is at risk of not reflecting real changes in working conditions. To rule out this possibility and validate the measure, we correlated country averages of reported public sector salary changes in the survey with real changes in the average remuneration of public administration officials from 2009 to 2010 according to Eurostat data for 26 countries (Eurostat 2016). The two are statistically significantly correlated $(\mathrm{r}=0.745)$. This suggests that our key independent variable measure does tap into real changes in working conditions in European public sectors. Note also that our key independent variable taps into changes in working conditions across the sectors included in the sample: there are no statistically significant differences in changes in working conditions between public employees in administrative, health and education sectors.

Our key moderating variable - value alignment - in turn is measured on a 5-point Likert scale with the survey question: "Your job involves tasks that are in conflict with your personal values." This measure has been adapted from Schaufeli (2015) and assesses the interplay between the values of the individual and the organization's value system (Liedtka 1989). In addition, we consider 11 control variables related to individual characteristics and organizational behavior (see Appendix for corresponding survey questions). These duplicate the most common correlates of work motivation and job satisfaction in prior studies (Bright 2008; Chalofsky 2003; Michaelson 2005; Kirkman and Shapiro 2001; Rynes, Gerhart, and Minette 2004; Steijn 2008; Wright and Pandey 2008; Xiao and Jintae Froese 2012). They include: gender, age, education, income, working hours, size of workplace, tenure, work pressure, autonomy, organizational involvement, feeling of work well done and useful 
work. Note that, with the inclusion of levels of income and working hours among controls, the study also ensures that our key explanatory variables are capturing changes in these variables since 2009 while keeping levels constant.

Since the present study relies on perceptual measures for the two dependent variables and some of the explanatory variables from the same respondent, common method bias may occur (Podsakoff and Organ 1986). To reduce the likelihood that respondents "edit their responses to be more socially desirable, lenient, acquiescent, and consistent with how they think the researcher wants them to respond" (Podsakoff et al. 2003, 888), respondent anonymity was guaranteed. In addition, the questions pertaining to the predictors and criterion variables were segmented into different sections of the survey as recommended by Podsakoff et al (2003). Thus, while common-method bias cannot be ruled out, the aforementioned duties of care suggest that it is not a significant problem in the context of this research.

\section{Results}

In order to test the hypotheses, we conduct six hierarchical linear regression models, three for each of our two dependent variables: job satisfaction and work motivation. This is an appropriate approach given the two-level hierarchical nature of our data, which groups individuals (level 1) into countries (level 2). Thus, in this analysis we recognize that public sector employees within a particular country may be more similar to one another than employees in other countries (Hofmann 1997). In this vein, hierarchical linear regression models overcome the problem of independent observations derived from our large-N cross-European sample (Osborne 2000). 


\section{Descriptive statistics}

Table 1 displays the binary correlation table. Note that there are no multicollinearity problems biasing the results (Bowerman and O'Connell 1990; Menard 1995). The correlations between the control and explanatory variables are low to moderate. In addition, the average coefficient of the variance inflation factors (VIF) used to assess multicollinearity is 1.20 and all the factors are below 2 .

[Table 1 here]

\section{Analysis}

We now turn to presenting the results of the hierarchical linear models for job satisfaction (table 2) and work motivation (table 3) respectively. In each of the tables, Model 1 includes only the control variables. Model 2 adds our main explanatory variable (working conditions). Model 3 considers the hypothesized interaction effect between working conditions and value alignment.

Comparing differences in the log likelihood between Model 1 and Model 2 suggests that changing working conditions after 2009 are a powerful explanatory factor for both job satisfaction and motivation. In the case of job satisfaction, the log likelihood is reduced from 3,723 to 3,097 (table 2); in the case of work motivation, the log likelihood decreases from 5,204 to 4,359 (table 3). In both cases, the overall fit of the hierarchical linear models is statistically significantly improved by adding working conditions as an explanatory variable.

[Table 2 here]

[Table 3 here] 
Significance extends not only to our three models but also the causal effects of changing working conditions. As illustrated in table 2, deteriorations in working conditions in 2009-2010 are associated with significantly lower job satisfaction of employees $\left(\beta_{\text {change in working conditions }}=.118\right.$, S.E. $\left.=.016, \mathrm{p}<.001\right)(\operatorname{model} 2)$. This finding provides empirical support for our first hypothesis.

Deteriorations in working conditions, similarly, exerted a significant effect on work motivation (table 3 ). They are associated with significantly lower work motivation $\left(\beta_{\text {change in working conditions }}=.113\right.$, S.E. $\left.=.024, \mathrm{p}<.001\right)$, confirming hypotheses $2($ model 2). Salary cuts and greater work demands thus diminished motivation levels of employees in 2009-2010.

Turning to the moderating effect of value alignment, we find - contrary to our third hypothesis - no significant interaction effect between value alignment and working conditions (model 3). In other words, the negative effect of worse working conditions on job satisfaction is not moderated when employees' personal values are aligned with organizations. Our expectation that value alignment moderates employee exhaustion with worse working conditions - and thus part of their negative effect on job satisfaction - is thus not confirmed. As a caveat, note, however, that multicollinearity puts a premium on caution in interpreting the insignificance of this interaction. The interaction term is significantly correlated with changes in working conditions (0.66). With its addition, the mean VIF increases to 5,25, with high VIFs for the interaction effect (29.19), value alignment (16.18) and changes in working conditions (14.85). Multicollinearity between these three variables may thus detract from statistical significance. 
Contrary to the case of job satisfaction, value alignment does moderate the effect of working conditions in the case of work motivation (model 3). The interaction effect is significant at the 5\%-level. This suggests that, if employees perceive that their personal values are aligned with their jobs, the effects of negative working conditions on motivation are attenuated.

Adding confidence in the validity of estimates, the remaining control variables are largely congruent with most prior studies (cf. Cantarelli, Belardinelli, and Belle 2015; Cameron, Banko, and Pierce 2001). First, job characteristics matter for both job satisfaction and work motivation. Our results thus confirm previous research showing the effects of organizational involvement on the motivation and job satisfaction of public employees (Brooke, et al., 1988; Brown, 1996). In addition, more autonomy among employees, higher levels of organizational involvement, having the feeling of doing work well done, doing useful work, and having values that are aligned with the organization are positively and significantly related at the $5 \%$ level or above to both job satisfaction and motivation. Second, greater work pressure impairs job satisfaction - albeit not motivation $(\mathrm{p}<.01)$. When employees have to work at high speed and under tight deadlines, they are less satisfied with - yet equally motivated to do - their jobs. Third, demographic characteristics matter, although differentially for job satisfaction and work motivation. The older an employee gets, the less satisfied - yet not less motivated - they will be with their job $(\mathrm{p}<.05)$. At the same time, women are associated with higher work motivation than men, yet not more job satisfaction ( $p$ $<.01)$.

Disaggregating this analysis into distinct European regions enables us to add further evidence in favor of our main hypotheses. Prior research based on the Coordinating 
for Cohesion in the Public Sector of the Future (COCOPS) survey identified a strong public sector North-South divide in post-2009 Europe (see, Hammerschmid et al 2016; Greve, Lægreid and Rykkja 2016). When testing for differences between the effect of our key independent variable - changes in working conditions - on work motivation and job satisfaction across Northern, Southern, Eastern and Western Europe, we find a similar divide. In Southern Europe, the effect of changes in working conditions on job satisfaction is significantly larger than in the remainder of Europe. In Northern Europe, the effect of changes in working conditions on job satisfaction is significantly smaller - and, in fact, not statistically different from zero (see tables A1 to A4 in the Appendix). We find no significant differences between Western and Eastern Europe and the European average. These results suggest that our findings may not extend to Northern Europe. At the same time, the congruence of this North-South divide with prior research adds further confidence in the validity of our overall results.

\section{Robustness Checks}

Several robustness checks lend further credence to our findings. First, we find that moderators identified in prior studies - autonomy and job insecurity - do not detract from the significance of most of our findings. Van der Voet and Van de Walle (2015) argue that autonomy moderates the relationship between cutback measures and job satisfaction. We find empirical support for this assertion for job satisfaction. At the same time, autonomy is - contrary to value alignment - not a significant moderator for work motivation (see table A5 in the Online Appendix). Conway et al. (2014) in turn argue that job security should be taken into account as a moderator for the effect of worse working conditions. We control for this, but do not find empirical support 
for this assertion. Our core results remain significant with either of these additional interactions (see table A6 in the Online Appendix).

Second, we included level-2 variables to account for the fact that some countries were more affected by the recession than others. Our level-1 variables - on changes in pay and working hours in the public sector - of course reflect part of the cross-country variation in recessions. Beyond their impact on public sector working conditions, however, recessions can affect publics sector work motivation and job satisfaction through other mechanisms, for instance by curtailing the attractiveness of private sector employment. We thus re-ran all models with a recession proxy as a level-2 variable: 2009-2010 changes in per capita incomes. Our results remain robust to this specification (see table A7 in the Online Appendix).

\section{Discussion}

In sum, the results provide strong confirmatory evidence for a negative effect of pay cuts and longer working hours in 2009-2010 on both job satisfaction and work motivation. There are thus no free austerity lunches: while public employees in Europe may work longer hours at lower pay, they are less satisfied and less motivated to perform for their organizations when doing so.

The effect on job satisfaction is congruent with both job-demands theory - worse working conditions exhaust employees and thus decrease their satisfaction - and psychological contract theory - cutbacks are perceived as breaches of contract which curb employee satisfaction (Bakker and Demerouti 2007; Rousseau 2001). The effect also provides further confirmatory evidence for a range of prior studies of job satisfaction (see Cantarelli, Belardinelli, and Belle 2015). Notwithstanding the lesser 
importance public employees place on economic rewards (De Graaf and van der Wal 2008), their job satisfaction thus falls when working conditions deteriorate.

The effect we identified on work motivation in turn adds important empirical evidence to the, so far, scarce studies associating resource reductions in the public sector with lower motivation (Levine 1979; Kiefer et al. 2015; Lindorff, Worral, and Cooper 2011). The finding is, furthermore, compatible with social exchange and psychological contract theory (Lavelle, Rupp, and Brockner 2007; Rousseau 2001). Public employees in Europe appear to respond to reduced perceived effort from their organizations towards them in times of austerity - a contract breach - with decreases in their own work motivation.

The results, however, do point to one cautious reason for hope: the effect of worse working conditions on work motivation was moderated by value alignment. Greater value alignment thus shielded the work motivation - albeit not job satisfaction - of public employees during pay cuts and greater work demands. This confirms the theoretical expectation derived from psychological contract theory (Rousseau 2001). With value alignment, the pursuit of organizational values - rather than pay and shorter working hours - becomes more important in psychological contracts. Worse working conditions thus come to constitute a lesser breach of contract. Value alignment is thus not only a significant positive contributor to bureaucratic behavior in its own right, as prior studies had emphasized (Paarlberg and Perry 2007; Grant 2008; Wright 2007), but can also act as an important moderator of deteriorations in other determinants of bureaucratic behavior and attitudes. 
The policy implication is clear: public sector leaders should put a premium on measures to strengthen value alignment particularly when it is arguably hardest to achieve: in times of cutbacks.

\section{Conclusion}

Our study offers significant contributions to the scholarly understanding of both austerity governance and bureaucratic job attitudes. First, it provides the most largescale empirical evidence to-date on the effects that austerity measures imposed since 2009 had among European public sector employees. It finds that pay cuts and longer working hours dampened both job satisfaction and work motivation. This is congruent with a range of pre-Great Recession studies linking income and working hours with job attitudes (Baltes et al. 1999; Cantarelli, Belardinelli, and Belle 2015; Clark and Oswald 1996; Judge et al. 2010; Nanda and Browne 1977). Austerity measures thus do appear to have damaging consequences for job attitudes.

This, of course, does not mean that all is lost. At least in 2010, public employees in all European countries were still on average more satisfied than dissatisfied with their jobs. Similarly, work motivation scores were on average above the mean of the scale in public sectors of all European countries. Our results, however, do shed doubt on the extent to which governments can turn 'doing more with less' mantras into practice. Public employees are central agents to achieve more with less - yet austerity-induced pay cuts and work demands decrease both their job satisfaction and work motivation. Doing less with less may thus well be a more accurate description of organizational behavior after the Great Recession. 
Second, the study exploited the empirical setting offered by the Great Recession with austerity measures implemented across a range of countries - to conduct a largescale test of prior theories of job satisfaction and work motivation. In doing so, it added, most notably, to existing studies which argued for the fundamental importance of value alignment for public sector organizations (Brown 1976; Grant 2008;

Paarlberg and Perry 2007; Wright 2007). The study suggests that value alignment not only enhances work motivation and job satisfaction as prior studies had noted. It, additionally, shields the work motivation of public employees when public organizations undertake cutbacks. This underscores the central, beneficial role of value alignment in times of organizational decline. At the same time, it points to a lifeline for public managers pursuing the Holy Grail of 'more with less': safeguard employee work motivation by ensuring their values are aligned with those of the organization and their jobs.

This conclusion also underscores the utility of further research on austerity and public sector workforces. Doing more with less is a central challenge for post-Great Recession public sectors, with a panoply of U.S. state and local governments, postBrexit Britain and Greece, among many, facing continued pressure to impose fiscal cuts. Public employees play a crucial role in overcoming this 'doing more with less' challenge. Yet, research on how the Great Recession has affected public employees, and what public sector organizations can do to retain and motivate public employees in austerity contexts remains scarce. Our analysis sheds light on these questions. It does have some limitations. To begin with, it covers only European countries, not austerity in other regions and countries. Future studies would do well to expand the geographic scope of inquiry. Moreover, the paper assesses the effect of austerity on only two attitudes of public servants, work motivation and job satisfaction. Austerity 
may well be expected to affect a range of other work-related attitudes and behaviors. Future studies could explore our arguments further by distinguishing, for example, the effects of pay cuts and long working hours on intrinsic and extrinsic motivation. It would be of great interest to see if cutbacks deteriorate the prosocial motivation of public service employees. Another interesting venue for future research is to develop a more complete assessment of value alignment among an individual's values and those of the organization where he or she works - for instance by assessing which values matter in terms of alignment - to understand in more depth how value alignment relates to motivation and job satisfaction.

A second limitation is that the data represent only public employees who remained in the public sector after the onset of the Great Recession. Panel data would be required to also study those who left - who, likely, saw the greatest decline in satisfaction and motivation. Much fertile empirical ground to study the relationship between austerity and organizational behavior and attitudes in the public sector thus remains. 


\section{Notes}

${ }^{1}$ Due to item non-response, the full models of the regression analyses in Tables 2 and 3 only include responses from 3,199 of the 9,761 public employee respondents. 82 percent of the decrease in observations from the full public employee sample to those included in the regression is due to non-response to four variables: work pressure, organizational involvement, income and working conditions. To assess potential nonresponse bias, we tested whether survey respondents who did not respond to these items differed in our other explanatory variables from those who did. We found no statistically significant differences between the two groups in terms of gender and education, thus providing some suggestive evidence that item non-response does not bias our results. 


\section{References}

Bakker, Arnold B. and Evangelia Demerouti. 2007. The Job Demands-Resources Model: State of the Art. Journal of Managerial Psychology 22(3): 309-328.

Baltes, Boris, Thomas E. Briggs, Joseph W. Huff, Julie A. Wright, and George A. Neuman. 1999. Flexible and Compressed Workweek Schedules: A MetaAnalysis of their Effects on Work-Related Criteria. Journal of Applied Psychology 84(4): 496-513.

Beckers, Debby, Dimitri van der Linden, Peter Smulders, Michiel Kompier, Marc van Veldhoven, and Nico van Yperen. 2004. Working Overtime Hours: Relations with Fatigue, Work Motivation, and the Quality of Work. Journal of Occupational \& Environmental Medicine 46(12): 1282-1289.

Brooke, Paul P., Daniel W. Russell, and James L. Price. 1988. Discriminant Validation of Measures of Job Satisfaction, Job Involvement, and Organizational Commitment. Journal of Applied Psychology 73(2): 139-145.

Bowerman, Bruce L. and Richard O'Connell. 1990. Linear Statistical Models: An Applied Approach (2nd ed.). Belmont, CA: Duxbury.

Bozeman, Barry. 2010. Hard Lessons from Hard Times: Reconsidering and Reorienting the "Organizational Decline" Literature. Public Administration Review 70(4): 557-63.

Brown, Martha A. 1976. Values - A Necessary but Neglected Ingredient of Motivation on the Job. Academy of Management Review 1(4): 15-23. 
Brown, Stephen P. 1996. A Meta-analysis and Review of Organizational Research on Job Involvement. Psychological Bulletin 120(2): 235-255.

Bright, Leonard. 2008. Does Public Service Motivation Really Make a Difference on the Job Satisfaction and Turnover Intentions of Public Employees? American Review of Public Administration 38(2): 149-166.

Cameron, Judy, Katherine M. Banko, and W. David Pierce. 2001. Pervasive Negative Effects of Rewards on Intrinsic Motivation. The Behavior Analyst 24(1): 1-44.

Cantarelli, Paola, Paolo Belardinelli, and Nicola Bellé. 2015. A Meta-Analysis of Job Satisfaction Correlates in the Public Administration Literature. Forthcoming at the Review of Public Personnel Administration.

Chalofsky, Neal. 2003. An Emerging Construct for Meaningful Work. Human Resource Development International 6(1): 69-83.

Clark, Andrew E., and Andrew J. Oswald. 1996. Satisfaction and Comparison Income. Journal of Public Economics 61(3): 395-381.

Conway, Neil, Tina Kiefer, Jean Hartley, and Rob B. Briner. 2014. Doing More with Less? Employee Reactions to Psychological Contract Breach via Target Similarity or Spillover During Public Sector Organizational Change. British Journal of Management 25(4): 737-754.

Daniels, Kevin. 2004. Perceived Risk from Occupational Stress: A Survey of 15 European Countries. Occupational and Environmental Medicine 61(5): 467.

De Graaf, Gjalt, and Zeger van der Wal. 2008. On Value Differences Experienced by Sector Switchers. Administration \& Society 40(1): 79-103. 
Di Mascio, Fabrizio, and Alessandro Natalini. 2015. Fiscal Retrenchment in Southern Europe: Changing Patterns of Public Management in Greece, Italy, Portugal and Spain. Public Management Review 17(1): 129-148.

Dolbier, Christyn L., Judith A. Webster, Katherine T. McCalister, Mark W. Mallon, and Mary A. Steinhardt. 2004. Reliability and Validity of a Single-Item Measure of Job Satisfaction. American Journal of Health Promotion 19(3): 194-198.

Eurostat. 2016. Remuneration of national civil servants in central public administration. $\quad$ Accessed $\quad$ November $\quad 3, \quad 2016$. http://appsso.eurostat.ec.europa.eu/nui/show.do?dataset=prc_rem_cs\&lang=en

Forni, Lorenzo, and Natalija Novta. 2014. Public Employment and Compensation Reform During Times of Fiscal Consolidation. Working Paper No. 14/192. Washington DC: International Monetary Fund.

Frey, Bruno S. 1997. Not Just for the Money. An Economic Theory of Personal Motivation. Cheltenham, UK and Brookfield, USA: Edward Elgar.

Furnham, Adrian. 2002. The Psychology of Behavior at Work, 2nd ed. Psychology Press, London.

Furnham, Adrian, Adrian Eracleous, and Tomas Chamorro-Premuzic. 2009. Personality, Motivation and Job Satisfaction: Hertzberg Meets the Big Five, Journal of Managerial Psychology 24(8): 765 - 779.

Gallup Europe. 2010. " $5^{\text {th }}$ European Working Conditions Survey, 2010 - Technical Report." European Foundation for the Improvement of Living and Working 
$\begin{array}{llll}\text { Conditions. } & \text { Accessed } & \text { August } & 18,\end{array}$ http://www.eurofound.europa.eu/sites/default/files/ef_files/surveys/ewcs/2010 /documents/technical.pdf

Grant, Adam. 2008. Employees without a Cause: The Motivational Effects of Prosocial Impact in Public Service, International Public Management Journal 11(1): 4866.

Greve, Carsten, Per Lægreid and Lise Rykkja (2016) Nordic Administrative Reforms: Lessons for Public Management. London: Palgrave.

Hammerschmid, Gerhard, Steven Van de Walle, Rhys Andrews and Philippe Bezes. (Eds.) (2016) Public Administration Reforms in Europe: The View from the Top. Cheltenham: Edward Elgar.

Hofmann, David. 1997. An Overview of the Logic and Rational of Hierarchical Linear Models. Journal of Management 23(6): 723-744.

Hofstede, Geert. 1980. Culture's Consequences: International Differences in WorkRelated Values. London: Sage Publications.

Hood, Christopher. 2010. Reflections on Public Service Reform in a Cold Fiscal Climate. London, UK: ESRC/Royal Society of the Arts.

Homer, Pamela, and Lynn R. Kahle. 1988. A Structural Equation Test of the ValueAttitude-Behavior Hierarchy. Journal of Personality and Social Psychology 54(4): 638-646. 
Judge, Timothy, Ronald Piccolo, Nathan Podsakoff, John Shawd, and Bruce Riche. 2010. The Relationship between Pay and Job Satisfaction: A Meta-analysis of the Literature. Journal of Vocational Behavior 77(2): 157-167.

Karanikolos, Marina, Philipa Mladovsky, Jonathan Cylus, Sarah Thomson, Sanjay Basu, David Stuckler, Johan Mackenbach, and Martin McKee. 2013. Financial Crisis, Austerity, and Health in Europe. The Lancet 381(9874): 13-19.

Kiefer, Tina, Jean Hartley, Neil Conway, and Rob Briner. 2015. Feeling the Squeeze: Public Employees' Experiences of Cutback and Innovation-related Organizational Changes Following a National Announcement of Budget Reductions. Journal of Public Administration Research and Theory 25(4): $1279-1305$.

Kim, Sangmook, and Wouter Vandenabeele. 2010. A Strategy for Building Public Service Motivation Research Internationally. Public Administration Review 70(5): 701-709.

Kirkman, Bradley and Debra Shapiro. 2001. The Impact of Cultural Values on Job Satisfaction and Organizational Commitment in Self-Managing Work Teams: The Mediating Role of Employee Resistance. Academy of Management Journal 44(3): 557-569.

Lavelle, James, Deborah Rupp, and Joel Brockner. 2007. Taking a Multifoci Approach to the Study of Justice, Social Exchange, and Citizenship Behavior: The Target Similarity Model. Journal of Management 33(6): 841-866.

Liedtka, Jeanne M. 1989. Value Congruence: The Interplay of Individual and Organizational Value Systems. Journal of Business Ethics 8(10): 805-815. 
Leiter, Michael, Erica Frank, and Timothy Matheson. 2009. Demands, Values, and Burnout: Relevance for Physicians. Canadian Family Physician 55(2): 12241225 .

Leslie, Keith, and Adam Canwell. 2010. Leadership at All Levels: Leading Public Sector Organizations in an Age of Austerity. European Management Journal 28(4): 297-305.

Levine, Charles. 1979. More on Cutback Management: Hard Questions for Hard Times. Public Administration Review 39(2):179-83.

Lindorff, Margaret, Les Worrall, and Cary Cooper. 2011. Managers' Wellbeing and Perceptions of Organizational Change in the UK and Australia. Asia Pacific Journal of Human Resources 49(2): 233-254.

Lodge, Martin, and Christopher Hood. 2012. Into an Age of Multiple Austerities? Public Management and Public Service Bargains across OECD Countries. Governance 25(1): 79-101.

Menard, Scott. 1995. Applied Logistic Regression Analysis. Sage University Paper Series On Quantitative Applications in the Social Sciences. Thousand Oaks, CA: Sage.

Michaelson, Christopher. 2005. Meaningful Motivation for Work Motivation Theory. Academy of Management Review 30(2): 235-238.

Nagy, Mark S. 2002. Using a Single-item Approach to Measure Facet Job Satisfaction. Journal of Occupational and Organizational Psychology 75(1): 77-86. 
Nanda, Ravinder, and James J. Browne. 1977. Hours of Work, Job Satisfaction and Productivity. Public Productivity Review 2(3): 46-56.

OECD. 2012. Public Sector Compensation in Times of Austerity. Paris: OECD

Osborne, Jason W. 2000. Advantages of Hierarchical Linear Modeling. Practical Assessment, Research \& Evaluation 7(1): 1-3.

Paarlberg, Laurie E., and James L. Perry. 2007. Values Management: Aligning Employee Values and Organizational Goals. American Review of Public Administration 37(4): 387-408.

Pandey, Sanjay. 2010. Cutback Management and the Paradox of Publicness. Public Administration Review 70(4):564-71.

Paoli, Pascal, and Damien Merllié. 2001. Third European Survey on Working Conditions 2000, Luxemburg: Office for Official Publications of the European Communities.

Perry, James L., and Lyman W. Porter. 1982. Factors Affecting the Context for Motivation in the Public Sector. Academy of Management Review 7(1): 89-98.

Perry, James L., Annie Hondeghem, and Lois Recascino Wise. 2010. Revisiting the Motivational Bases of Public Service: Twenty Years of Research and an Agenda for the Future. Public Administration Review 70(5): 681-690.

Perry, James L., and Lois Recascino Wise. 1990. The Motivational Bases of Public Service. Public Administration Review 50(3): 367-373.

Podsakoff, Philip M., Scott B. MacKenzie, Jeong-Yeon Lee, and Nathan P. 
Podsakoff. 2003. Common Method Biases in Behavioral Research: A Critical Review of the Literature and Recommended Remedies. Journal of Applied Psychology 88(5):879-903.

Podsakoff, Philip M., and Dennis W. Organ. 1986. Self-reports in Organizational Research: Problems and Prospects. Journal of Management 12(4):531-44.

Raudla, Ringa, James W. Douglas, Tiina Randma-Liiv, and Riin Savi. 2015. The Impact of Fiscal Crisis on Decision-Making Processes in European Governments: Dynamics of a Centralization Cascade. Public Administration Review 75(6): 842852.

Rokeach, Milton. 1968. Beliefs, Attitudes, and Values: A Theory of Organization and Change. San Francisco: Jossey-Bass.

Rousseau, Denise M. 2001. Schema, Promise and Mutuality: The Building Blocks of the Psychological Contract. Journal of Occupational and Organizational Psychology 74(4): 511-541.

Rynes, Sara L., Barry Gerhart, and Kathleen A. Minette. 2004. The Importance of Pay in Employee Motivation: Discrepancies between What People Say and What they Do. Human Resource Management 43(4): 381-394.

Schaufeli, Wilmar B. 2015. Engaging leadership in the Job Demands-Resources Model. Career Development International 20(5): 446-463.

Steijn, Bram. 2008. Person-environment Fit and Public Service Motivation. International Public Management Journal 11(1): 13-27. 
van der Voet, Joris, and Brenda Vermeeren. 2016. Change Management in Hard Times: Can Change Management Mitigate the Negative Relationship Between Cutbacks and the Organizational Commitment and Work Engagement of Public Sector Employees? Forthcoming at the American Review of Public Administration.

van der Voet, Joris, and Steven Van de Walle. 2015. How Cutbacks and Job Satisfaction Are Related: The Role of Top-Level Public Managers’ Autonomy. Forthcoming at Review of Public Personnel Administration.

van Witteloostuijn, Arjen, Marc Esteve, and George Boyne. 2017. Public Service Motivation Ad Fonts: Personality Traits as Antecedents to Serve the Public Interest. Journal of Public Administration Research and Theory 27(1): 20-35.

Vroom, Victor H. 1964. Work and Motivation. San Francisco, CA: Jossey-Bass.

Wanous, John P., Arnon E. Reichers, and Michael J. Hurdy. 1997. Overall Job Satisfaction: How Good Are Single Item Measures? Journal of Applied Psychology 82(2):247-252.

Weibel, Antoinette, Katja Rost, and Margit Osterloh. 2010. Pay for Performance in the Public Sector - Benefits and (Hidden) Costs. Journal of Public Administration Research and Theory 20(2): 387-412.

Wright, Bradley E. 2007. Public Service Motivation: Does Mission Matter? Public Administration Review 67(1): 54-64. 
Wright, Bradley E., and Sanjay K. Pandey. 2008. Public Service Motivation and the Assumption of Person-organization Fit: Testing the Mediating Effect of Value Congruence. Administration \& Society 40(5): 502-52.

Xiao, Shufeng, and Fabian Jintae Froese. 2012. Work Values, Job Satisfaction and Organizational Commitment in China. International Journal of Human Resource Management 23(10): 2144-2162. 
Table 1. Binary correlations

\begin{tabular}{|c|c|c|c|c|c|c|c|c|c|c|c|c|c|c|c|c|}
\hline & 1 & 2 & 3 & 4 & 5 & 6 & 7 & 8 & 9 & 10 & 11 & 12 & 13 & 14 & 15 & 16 \\
\hline \multicolumn{17}{|l|}{ 1. Job satisfaction } \\
\hline 2. Motivation & $.383^{*}$ & & & & & & & & & & & & & & & \\
\hline 3. Gender & .015 & $.043^{*}$ & & & & & & & & & & & & & & \\
\hline 4. Age & $-.037 *$ & $-.030 *$ & $.022 *$ & & & & & & & & & & & & & \\
\hline 5. Education & $.067 *$ & $.051 *$ & $.079 *$ & $-.111^{*}$ & & & & & & & & & & & & \\
\hline 6. Income & -.007 & $.039 *$ & .010 & $.050 *$ & $.065^{*}$ & & & & & & & & & & & \\
\hline $\begin{array}{l}\text { 7. Size of } \\
\text { workplace }\end{array}$ & $-.024 *$ & $-.044 *$ & $-.055^{*}$ & -.015 & $.094 *$ & $.043^{*}$ & & & & & & & & & & \\
\hline 8. Tenure & $-.040 *$ & -.011 & $-.022 *$ & $.584^{*}$ & $-.038 *$ & -.001 & $.081^{*}$ & & & & & & & & & \\
\hline 9. Working hours & $-.088 *$ & $-.041 *$ & $-.150 *$ & .015 & $-.028 *$ & $.078 *$ & $.039 *$ & $.062 *$ & & & & & & & & \\
\hline 10. Work pressure & $-.101 *$ & $-.030 *$ & $.039 *$ & $-.027 *$ & $-.039 *$ & -.001 & $.086^{*}$ & -.005 & $.071 *$ & & & & & & & \\
\hline 11. Autonomy & $.127 *$ & $.096^{*}$ & $.091 *$ & $.049 *$ & $.190 *$ & $.061 *$ & $-.040 *$ & .017 & $-.063^{*}$ & $-.117^{*}$ & & & & & & \\
\hline $\begin{array}{l}\text { 12. Org. } \\
\text { involvement }\end{array}$ & $.203 *$ & $.267 *$ & -.001 & .009 & $.194^{*}$ & $.041 *$ & $-.026^{*}$ & $.031 *$ & .006 & $.030^{*}$ & $.241 *$ & & & & & \\
\hline 13. Work well done & $.259 *$ & $.302 *$ & .015 & .017 & -.010 & -.000 & $-.061 *$ & $.027 *$ & $-.037 *$ & $-.034 *$ & $.076^{*}$ & $.205^{*}$ & & & & \\
\hline 14. Useful work & $.198 *$ & $.283 *$ & $.042 *$ & $.032 *$ & $.060 *$ & .015 & $-.046^{*}$ & $.051 *$ & $-.025^{*}$ & .016 & $.108 *$ & $.215^{*}$ & $.577 *$ & & & \\
\hline $\begin{array}{l}15 . \text { Value } \\
\text { alignment }\end{array}$ & $.115^{*}$ & $.073 *$ & .007 & $.040^{*}$ & -.015 & .020 & -.016 & $.022 *$ & $-.051 *$ & $-.106^{*}$ & -.005 & $-.095^{*}$ & $.128 *$ & $.110 *$ & & \\
\hline $\begin{array}{l}\text { 16. Change in } \\
\text { Working conditions }\end{array}$ & $.143 *$ & $.123^{*}$ & $-.053^{*}$ & -.018 & .020 & $.055^{*}$ & $.054^{*}$ & -.001 & $-.098^{*}$ & $-.041 *$ & $.041 *$ & .016 & $.042 *$ & $.038 *$ & .018 & \\
\hline $\begin{array}{l}\text { 17. Change in } \\
\text { Working } \\
\text { Conditions* Value } \\
\text { alignment }\end{array}$ & .015 & $.031 *$ & $-.040 *$ & $-.052^{*}$ & $.026^{*}$ & .024 & $.047 *$ & $-.031 *$ & $-.040 *$ & $.051 *$ & $.033^{*}$ & $.075^{*}$ & $-.064 *$ & $-.054 *$ & $-.716^{*}$ & $.661 *$ \\
\hline
\end{tabular}

Note: $* p<.05$ 
Table 2. Regression: Job satisfaction

\begin{tabular}{lccc} 
Predictor & Model 1 & Model 2 & Model 3 \\
\hline Gender & $-.034(.022)$ & $-.028(.024)$ & $-.026(.024)$ \\
Age & $-.002(.001)^{*}$ & $-.003(.001)^{*}$ & $-.003(.001)^{*}$ \\
Education & $.001(.009)$ & $.006(.009)$ & $.007(.010)$ \\
Income & $4.70 \mathrm{e}-07(9.44 \mathrm{e}-07)$ & $-1.24 \mathrm{e}-07(9.61 \mathrm{e}-07)$ & $-1.45 \mathrm{e}-07(9.59 \mathrm{e}-07)$ \\
Size of workplace & $.006(.006)$ & $.008(.007)$ & $.008(.007)$ \\
Tenure & $-.001(.001)$ & $4.77 \mathrm{e}-05(.001)$ & $-4.09 \mathrm{e}-05(.001)$ \\
Working hours & $-.002(.001)$ & $-.003(.001)^{*}$ & $-.003(.001)^{*}$ \\
Work pressure & $-.048(.007)^{* * *}$ & $-.042(.007)^{* * *}$ & $-.042(.007)^{* * *}$ \\
Autonomy & $.039(.010)^{* * *}$ & $.034(.011)^{* *}$ & $.034(.011)^{* *}$ \\
Organizational involvement & $.100(.011)^{* * *}$ & $.096(.012)^{* * *}$ & $.096(.012)^{* * *}$ \\
Work well done & $.136(.015)^{* * *}$ & $.135(.016)^{* * *}$ & $.134(.016)^{* * *}$ \\
Useful work & $.062(.015)^{* * *}$ & $.058(.017)^{* *}$ & $.057(.016)^{* *}$ \\
Value alignment & $.064(.009)^{* * *}$ & $.053(.010)^{* * *}$ & $.112(.039)^{* *}$ \\
Change in working conditions & & $.118(.016)^{* * *}$ & $.036(.056)$ \\
Change in working conditions $*$ Value alignment & & & $.020(.013)$ \\
Country Level Intercept & $1.915(.118)^{* * *}$ & $2.340(.140)^{* * *}$ & $2.097(.211)^{* * *}$ \\
Log likelihood & $-3,699.032$ & $-3,081.451$ & $-3,080.269$ \\
N & 3,828 & 3,199 & 3,199
\end{tabular}

Notes: Hierarchical linear model regression coefficients with standard errors in parentheses.

$* * * \mathrm{p}<.001 ; * * \mathrm{p}<.01 ; * \mathrm{p}<.05$ 
Table 3. Regression: Motivation

\begin{tabular}{lccc} 
Predictor & Model 1 & Model 2 & Model 3 \\
\hline \hline Gender & $.099(.033)^{* *}$ & $.112(.036)^{* *}$ & $.112(.035)^{* *}$ \\
Age & $-.001(.002)$ & $-.001(.002)$ & $-.001(.002)$ \\
Education & $-.016(.013)$ & $-.021(.014)$ & $-.020(.014)$ \\
Income & $2.14 \mathrm{e}-06(1.29 \mathrm{e}-06)$ & $2.09 \mathrm{e}-06(1.23 \mathrm{e}-06)$ & $2.05 \mathrm{e}-06(1.23 \mathrm{e}-06)$ \\
Size of workplace & $-.020(.009)^{*}$ & $-.017(.010)$ & $-.017(.010)$ \\
Tenure & $-.004(.002)^{*}$ & $-.004(.002)$ & $-.004(.002)$ \\
Working hours & $.002(.002)$ & $.001(.002)$ & $.001(.002)$ \\
Work pressure & $-.017(.010)$ & $-.014(.010)$ & $-.014(.010)$ \\
Autonomy & $.031(.015)^{*}$ & $.035(.016)^{*}$ & $.036(.016)^{*}$ \\
Organizational involvement & $.212(.016)^{* * *}$ & $.205(.018)^{* * *}$ & $.205(.018)^{* * *}$ \\
Work well done & $.233(.022)^{* * *}$ & $.251(.024)^{* * *}$ & $.249(.024)^{* * *}$ \\
Useful work & $.169(.023)^{* * *}$ & $.147(.025)^{* * *}$ & $.147(.025)^{* * *}$ \\
Value alignment & $.049(.014)^{* * *}$ & $.042(.015)^{* *}$ & $.164(.059)^{* *}$ \\
Change in working conditions & & $.113(.024)^{* * *}$ & $-.057(.083)$ \\
Change in working conditions $*$ Value alignment & & & $.042(.019)^{*}$ \\
Country Level Intercept & $.989(.172)^{* * *}$ & $1.389(.204)^{* * *}$ & $.885(.311)^{* *}$ \\
Log likelihood & $-5,163.675$ & $-4,332.620$ & $-4,330.332$ \\
N & 3,824 & 3,199 & 3,199
\end{tabular}

Notes: Hierarchical linear model regression coefficients with standard errors in parentheses.

$* * * \mathrm{p}<.001 ; * * \mathrm{p}<.01 ; * \mathrm{p}<.05$ 


\section{Appendix}

\begin{tabular}{|c|c|c|c|c|c|c|c|}
\hline \multicolumn{6}{|c|}{ Dependent variables } & & \\
\hline $\begin{array}{l}\text { Job } \\
\text { satisfaction }\end{array}$ & $\begin{array}{l}\text { On the whole, are you very satisfied, satisfied, not } \\
\text { very satisfied or not at all satisfied with working } \\
\text { conditions in your main paid job? }\end{array}$ & $\begin{array}{l}1=\text { Not at all satisfiec } \\
2=\text { Not very satisfied } \\
3=\text { Satisfied } \\
4=\text { Very satisfied }\end{array}$ & & 9,665 & 3.043 & .693 & $1-4$ \\
\hline Motivation & $\begin{array}{l}\text { The organization I work for motivates me to give my } \\
\text { best job performance. }\end{array}$ & $\begin{array}{l}1=\text { Strongly disagree } \\
2=\text { Disagree } \\
3=\text { Neither agree nor } \\
4=\text { Agree } \\
5=\text { Strongly agree }\end{array}$ & isagree & 9,541 & 3.609 & 1.049 & $1-5$ \\
\hline \multicolumn{8}{|c|}{ Control and Explanatory variables } \\
\hline Country & $\begin{array}{llll} & \\
\end{array}$ & $\begin{array}{l}1=\text { Belgium } \\
2=\text { Bulgaria } \\
3=\text { Czech Republic } \\
\text { 4=Denmark } \\
5=\text { Germany } \\
6=\text { Estonia } \\
7=\text { Greece } \\
8=\text { Spain } \\
9=\text { France } \\
10=\text { Ireland } \\
11=\text { Italy } \\
12=\text { Cyprus } \\
13=\text { Latvia } \\
14=\text { Lithuania } \\
\text { 15=Luxembourg } \\
16=\text { Hungary } \\
17=\text { Malta }\end{array}$ & $\begin{array}{l}18=\text { Netherlands } \\
19=\text { Austria } \\
20=\text { Poland } \\
21=\text { Portugal } \\
22=\text { Romania } \\
23=\text { Slovenia } \\
24=\text { Slovakia } \\
25=\text { Finland } \\
26=\text { Sweden } \\
27=\text { UK } \\
28=\text { Croatia } \\
29=\text { FYROM } \\
30=\text { Turkey } \\
31=\text { Norway } \\
32=\text { Albania } \\
33=\text { Kosovo } \\
34=\text { Montenegro }\end{array}$ & 9,761 & - & - & $1-34$ \\
\hline Gender & - & $\begin{array}{l}1=\text { Male } \\
2=\text { Female }\end{array}$ & & 9,761 & 1.611 & .487 & $1-2$ \\
\hline
\end{tabular}




\begin{tabular}{|c|c|c|c|c|c|c|}
\hline Age & - & 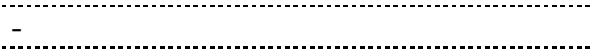 & 9,708 & 43.335 & 11.416 & $15-89$ \\
\hline Education & $\begin{array}{l}\text { What is the highest level of education or training that } \\
\text { you have successfully completed? }\end{array}$ & $\begin{array}{l}0=\text { Pre-primary education } \\
1=\text { Primary education } \\
2=\text { Lower secondary education } \\
3=\text { Upper secondary education } \\
5=\text { Post-secondary non-tertiary education } \\
5=\text { Tertiary education }- \text { first level } \\
6=\text { Tertiary education }- \text { advanced level }\end{array}$ & 9,738 & 3.743 & 1.273 & $0-6$ \\
\hline Income & $\begin{array}{l}\text { Please can you tell us how much are your net } \\
\text { monthly earnings from your main paid job? }\end{array}$ & 1 & 6,848 & $8,198.37$ & $20,133.58$ & $16.8-480,000$ \\
\hline $\begin{array}{l}\text { Size of } \\
\text { workplace }\end{array}$ & $\begin{array}{l}\text { How many people in total work at your workplace (at } \\
\text { the local site)? }\end{array}$ & $\begin{array}{l}1=1 \\
2=2-4 \\
3=5-9 \\
4=10-49 \\
5=50-99 \\
6=100-249 \\
7=250-499 \\
8=500 \text { and over }\end{array}$ & 9,359 & 4.510 & 1.706 & $1-8$ \\
\hline Tenure & $\begin{array}{l}\text { How many years have you been in your company or } \\
\text { organization? }\end{array}$ & - & 9,623 & 12.160 & 10.451 & $0-57$ \\
\hline $\begin{array}{l}\text { Working } \\
\text { hours }\end{array}$ & $\begin{array}{l}\text { How many hours do you usually work per week in } \\
\text { your main paid job? }\end{array}$ & . & 9,581 & 35.959 & 10.304 & $1-168$ \\
\hline $\begin{array}{l}\text { Work } \\
\text { pressure }\end{array}$ & $\begin{array}{l}\text { Does your job involve (1) working at a very high } \\
\text { speed and (2) working to tight deadlines. }\end{array}$ & $\begin{array}{l}1=\text { Never } \\
2=\text { Almost never } \\
3=\text { Around } 1 / 4 \text { of the time } \\
4=\text { Around half of the time } \\
5=\text { Around } 3 / 4 \text { of the time } \\
6=\text { Almost all the time } \\
7=\text { All the time }\end{array}$ & 6,379 & 4.046 & 1.594 & $2-7$ \\
\hline Autonomy & $\begin{array}{l}\text { Are you able to choose or change (1) your order of } \\
\text { tasks; (2) your methods of work; (3) your speed or } \\
\text { rate of work? }\end{array}$ & $\begin{array}{l}0=\mathrm{No} \\
1=\text { Yes }\end{array}$ & 9,544 & 2.027 & 1.153 & $0-3$ \\
\hline $\begin{array}{l}\text { Organization } \\
\text { involvement }\end{array}$ & $\begin{array}{l}\text { (1) you are consulted before targets for your work are } \\
\text { set; (2) you are involved in improving the work } \\
\text { organization or work processes of your department or }\end{array}$ & $\begin{array}{l}1=\text { Never } \\
2=\text { Rarely } \\
3=\text { Sometimes } \\
4=\text { Most of the times }\end{array}$ & 8,661 & 2.875 & 1.073 & $1-5$ \\
\hline
\end{tabular}




\begin{tabular}{|c|c|c|c|c|c|c|}
\hline & $\begin{array}{l}\text { organization; (3) you have a say in the choice of your } \\
\text { working partners }\end{array}$ & 5=Always & & & & \\
\hline $\begin{array}{l}\text { Work well } \\
\text { done }\end{array}$ & Your job gives you the feeling of work well done & $\begin{array}{l}1=\text { Never } \\
2=\text { Rarely } \\
3=\text { Sometimes } \\
4=\text { Most of the time } \\
5=\text { Always }\end{array}$ & 9,683 & 4.266 & .851 & $1-5$ \\
\hline Useful work & You have the feeling of doing useful work & $\begin{array}{l}1=\text { Never } \\
2=\text { Rarely } \\
3=\text { Sometimes } \\
4=\text { Most of the time } \\
5=\text { Always }\end{array}$ & 9,703 & 4.463 & .797 & $1-5$ \\
\hline $\begin{array}{l}\text { Value } \\
\text { alignment }\end{array}$ & $\begin{array}{l}\text { Your job involves tasks that are in conflict with your } \\
\text { personal values }\end{array}$ & $\begin{array}{l}1=\text { Always } \\
2=\text { Most of the time } \\
3=\text { Sometimes } \\
4=\text { Rarely } \\
5=\text { Never }\end{array}$ & 9,571 & 4.205 & 1.131 & $1-5$ \\
\hline $\begin{array}{l}\text { Working } \\
\text { conditions }\end{array}$ & $\begin{array}{l}\text { [Taking into account the changes in the number of } \\
\text { hours you work per week and your salary since } 2009 \text {, } \\
\text { your current working conditions are] }\end{array}$ & $\begin{array}{l}1=\text { Worse in working hours and salary } \\
2=\text { Worse in working hours or salary } \\
3=\text { Equal } \\
4=\text { Better in working hours or salary } \\
5=\text { Better in working hours and salary }\end{array}$ & 8,161 & 2.926 & .741 & $1-5$ \\
\hline
\end{tabular}


Table A1. Regression for Job Satisfaction \& Motivation - Eastern Europe

\begin{tabular}{|c|c|c|c|c|}
\hline \multirow{2}{*}{$\begin{array}{l}\text { Predictor } \\
\text { Gender }\end{array}$} & \multicolumn{2}{|c|}{ DV: Job satisfaction } & \multicolumn{2}{|l|}{ DV: Motivation } \\
\hline & $-.023(.024)$ & $-.025(.024)$ & $.118(.036)^{* *}$ & $.119(.036)^{* *}$ \\
\hline Age & $-.003(.001)^{*}$ & $-.003(.001)^{*}$ & $-.001(.002)$ & $-.001(.002)$ \\
\hline Education & $.006(.001)$ & $.006(.010)$ & $-.022(.014)$ & $-.023(.014)$ \\
\hline Income & $.000(.000)$ & $.000(.000)$ & $.000(.000)$ & $.000(.000)$ \\
\hline Size of workplace & $.008(.007)$ & $.008(.007)$ & $-.018(.011)$ & $-.017(.011)$ \\
\hline Tenure & $.000(.001)$ & $.000(.001)$ & $-.004(.002)^{*}$ & $-.004(.002)^{*}$ \\
\hline Working hours & $-.003(.001)^{*}$ & $-.003(.001)^{*}$ & $.001(.002)$ & $.001(.002)$ \\
\hline Work pressure & $-.042(.007) * * *$ & $-.042(.007) * * *$ & $-.014(.011)$ & $-.014(.011)$ \\
\hline Autonomy & $.034(.011)^{* *}$ & $.034(.011)^{* *}$ & $.035(.016)^{*}$ & $.035(.016)^{*}$ \\
\hline Organizational involvement & $.096(.012) * * *$ & $.096(.012) * * *$ & $.205(.018)^{* * *}$ & $.205(.018)^{* * *}$ \\
\hline Work well done & $.133(.016) * * *$ & $.134(.016) * * *$ & $.249(.024) * * *$ & $.250(.024) * * *$ \\
\hline Useful work & $.057(.017)^{* *}$ & $.057(.017)^{* *}$ & $.147(.025)^{* * *}$ & $.147(.025)^{* * *}$ \\
\hline Value alignment & $.111(.040)^{* *}$ & $.108(.039)^{* *}$ & $.161(.059)^{* *}$ & $.155(.059)^{* *}$ \\
\hline Change in working conditions & $.031(.056)$ & $.042(.056)$ & $-.064(.084)$ & $-.052(.083)$ \\
\hline Change in working conditions $*$ Value alignment & $.020(.013)$ & $.017(.013)$ & $.041(.019)^{*}$ & $.035(.020)$ \\
\hline Eastern countries & $.043(.169)$ & $.033(.121)$ & $.196(.240)$ & $.209(.168)$ \\
\hline Change in working conditions $*$ Eastern countries & $.047(.051)$ & - & $.089(.074)$ & - \\
\hline $\begin{array}{l}\text { Change in working conditions } * \text { Value alignment } * \\
\text { Eastern countries }\end{array}$ & & $.010(.008)$ & - & $.022(.011)$ \\
\hline Country Level Intercept & $2.097(.212)^{* * *}$ & $2.109(.211)^{* * *}$ & $.887(.311)^{* *}$ & $.892(.311)^{* *}$ \\
\hline Log likelihood & $-3,078.985$ & $-3,078.405$ & $-4,329.579$ & $-4,328.098$ \\
\hline $\mathrm{N}$ & 3,199 & 3,199 & 3,199 & 3,199 \\
\hline
\end{tabular}

Notes: Hierarchical linear model regression coefficients with standard errors in parentheses.

$* * * \mathrm{p}<.001 ; * * \mathrm{p}<.01 ; * \mathrm{p} \leq .05$ 
Table A2. Regression for Job Satisfaction \& Motivation - Northern Europe

\begin{tabular}{|c|c|c|c|c|}
\hline \multirow{2}{*}{$\begin{array}{l}\text { Predictor } \\
\text { Gender }\end{array}$} & \multicolumn{2}{|c|}{ DV: Job satisfaction } & \multicolumn{2}{|l|}{ DV: Motivation } \\
\hline & $-.027(.024)$ & $-.029(.024)$ & $.111(.036)^{* *}$ & $.110(.036) * *$ \\
\hline Age & $-.003(.001)^{*}$ & $-.003(.001)^{*}$ & $-.001(.002)$ & $-.001(.002)$ \\
\hline Education & $.006(.010)$ & $.006(.010)$ & $-.022(.014)$ & $-.023(.014)$ \\
\hline Income & $.000(.000)$ & $.000(.000)$ & $.000(.000)$ & $.000(.000)$ \\
\hline Size of workplace & $.008(.007)$ & $.008(.007)$ & $-.018(.010)$ & $-.017(.010)$ \\
\hline Tenure & $.000(.001)$ & $.000(.001)$ & $-.004(.002)$ & $-.004(.002)$ \\
\hline Working hours & $-.003(.001)^{*}$ & $-.003(.001)^{*}$ & $.001(.002)$ & $.001(.002)$ \\
\hline Work pressure & $-.042(.007) * * *$ & $-.041(.007) * * *$ & $-.014(.011)$ & $-.014(.011)$ \\
\hline Autonomy & $.033(.011)^{* *}$ & $.033(.011) * *$ & $.032(.016)^{*}$ & $.033(.016)^{*}$ \\
\hline Organizational involvement & $.094(.012)^{* * *}$ & $.094(.012)^{* * *}$ & $.203(.018)^{* * *}$ & $.203(.018)^{* * *}$ \\
\hline Work well done & $.136(.016) * * *$ & $.136(.016) * * *$ & $.253(.024) * * *$ & $.254(.024)^{* * *}$ \\
\hline Useful work & $.057(.017)^{* *}$ & $.056(.017)^{* *}$ & $.147(.025)^{* * *}$ & $.147(.025)^{* * *}$ \\
\hline Value alignment & $.110(.039)^{* *}$ & $.112(.039) * *$ & $.162(.058)^{* *}$ & $.163(.059) * *$ \\
\hline Change in working conditions & $.069(.058)$ & $.040(.056)$ & $-.025(.087)$ & $-.048(.083)$ \\
\hline Change in working conditions $*$ Value alignment & $.020(.013)$ & $.022(.013)$ & $.041(.019)^{*}$ & $.045(.019)^{*}$ \\
\hline Northern countries & $-.026(.109)$ & $.102(.083)$ & $-.034(.152)$ & $.024(.113)$ \\
\hline Change in working conditions $*$ Northern countries & $-.063(.032)^{*}$ & - & $-.058(.047)$ & - \\
\hline $\begin{array}{l}\text { Change in working conditions * Value alignment } * \\
\text { Northern countries }\end{array}$ & - & $-.004(.005)$ & - & $-.009(.008)$ \\
\hline Country Level Intercept & $2.158(.216)^{* * *}$ & $2.093(.213) * * *$ & $.951(.319)^{* *}$ & $.917(.313) * *$ \\
\hline Log likelihood & $-3,074.0965$ & $-3,075.563$ & $-4,327.287$ & $-4,327.320$ \\
\hline $\mathrm{N}$ & 3,199 & 3,199 & 3,199 & 3,199 \\
\hline
\end{tabular}

Notes: Hierarchical linear model regression coefficients with standard errors in parentheses.

$* * * \mathrm{p}<.001 ; * * \mathrm{p}<.01 ; * \mathrm{p} \leq .05$ 
Table A3. Regression for Job Satisfaction \& Motivation - Southern Europe

\begin{tabular}{|c|c|c|c|c|}
\hline \multirow{2}{*}{$\begin{array}{l}\text { Predictor } \\
\text { Gender }\end{array}$} & \multicolumn{2}{|c|}{ DV: Job satisfaction } & \multicolumn{2}{|l|}{ DV: Motivation } \\
\hline & $-.029(.024)$ & $-.029(.024)$ & $.112(.036)^{* *}$ & $.110(.036)^{* *}$ \\
\hline Age & $-.003(.001)^{*}$ & $-.003(.001)^{*}$ & $-.001(.002)$ & $-.001(.002)$ \\
\hline Education & $.007(.010)$ & $.007(.010)$ & $-.021(.014)$ & $-.021(.014)$ \\
\hline Income & $.000(.000)$ & $.000(.000)$ & $.000(.000)$ & $.000(.000)$ \\
\hline Size of workplace & $.007(.007)$ & $.008(.007)$ & $-.018(.011)$ & $-.018(.011)$ \\
\hline Tenure & $.000(.001)$ & $.000(.001)$ & $-.004(.002)$ & $-.004(.002)$ \\
\hline Working hours & $-.003(.001)^{*}$ & $-.003(.001)^{*}$ & $.001(.002)$ & $.001(.002)$ \\
\hline Work pressure & $-.042(.007) * * *$ & $-.041(.007)^{* * *}$ & $-.014(.011)$ & $-.013(.011)$ \\
\hline Autonomy & $.033(.011) * *$ & $.033(.011)^{* *}$ & $.034(.016)^{*}$ & $.034(.016)^{*}$ \\
\hline Organizational involvement & $.095(.012)^{* * *}$ & $.095(.012)^{* * *}$ & $.205(.018)^{* * *}$ & $.205(.018)^{* * *}$ \\
\hline Work well done & $.136(.016) * * *$ & $.136(.016)^{* * *}$ & $.251(.024) * * *$ & $.251(.024) * * *$ \\
\hline Useful work & $.058(.017)^{* *}$ & $.058(.017)^{* *}$ & $.148(.025)^{* * *}$ & $.148(.025)^{* * *}$ \\
\hline Value alignment & $.111(.039)^{* *}$ & $.112(.039) * *$ & $.163(.059)^{* *}$ & $.164(.059)^{* *}$ \\
\hline Change in working conditions & $.017(.057)$ & $.038(.056)$ & $-.064(.085)$ & $-.055(.083)$ \\
\hline Change in working conditions $*$ Value alignment & $.020(.013)$ & $.019(.013)$ & $.042(.019)^{*}$ & $.040(.020)^{*}$ \\
\hline Southern countries & $.076(.113)$ & $-.077(.082)$ & $.007(.160)$ & $-.130(.113)$ \\
\hline Change in working conditions * Southern countries & $0.67(.034)^{*}$ & - & $.025(.050)$ & - \\
\hline $\begin{array}{l}\text { Change in working conditions * Value alignment } * \\
\text { Southern countries }\end{array}$ & - & $.004(.005)$ & - & $.004(.008)$ \\
\hline Country Level Intercept & $2.094(.214) * * *$ & $2.137(.213) * * *$ & $.897(.316)^{* *}$ & $.898(.315) * *$ \\
\hline Log likelihood & $-3,075.916$ & $-3,077.567$ & $-4,329.627$ & $-4,329.585$ \\
\hline $\mathrm{N}$ & 3,199 & 3,199 & 3,199 & 3,199 \\
\hline
\end{tabular}

Notes: Hierarchical linear model regression coefficients with standard errors in parentheses.

$* * * \mathrm{p}<.001 ; * * \mathrm{p}<.01 ; * \mathrm{p} \leq .05$ 
Table A4. Regression for Job Satisfaction \& Motivation - Western Europe

\begin{tabular}{|c|c|c|c|c|}
\hline Predictor & DV: Job satisfac & & DV: Motivation & \\
\hline Gender & $-.027(.024)$ & $-.027(.024)$ & $.115(.036) * *$ & $.117(.036) * *$ \\
\hline Age & $-.003(.001)^{*}$ & $-.003(.001)^{*}$ & $-.001(.002)$ & $-.001(.002)$ \\
\hline Education & $.006(.010)$ & $.006(.010)$ & $-.021(.014)$ & $-.021(.014)$ \\
\hline Income & $.000(.000)$ & $.000(.000)$ & $.000(.000)$ & $.000(.000)$ \\
\hline Size of workplace & $.008(.007)$ & $.007(.007)$ & $-.017(.011)$ & $-.017(.010)$ \\
\hline Tenure & $.000(.001)$ & $.000(.001)$ & $-.004(.002)$ & $-.004(.002)$ \\
\hline Working hours & $-.003(.001)^{*}$ & $-.003(.001)^{*}$ & $.001(.002)$ & $.001(.002)$ \\
\hline Work pressure & $-.042(.007) * * *$ & $-.041(.007) * * *$ & $-.014(.011)$ & $-.014(.011)$ \\
\hline Autonomy & $.034(.011)^{* *}$ & $.034(.011)^{* *}$ & $.035(.016) *$ & $.035(.016)^{*}$ \\
\hline Organizational involvement & $.096(.012)^{* * *}$ & $.096(.012)^{* * *}$ & $.204(.018) * * *$ & $.204(.018) * * *$ \\
\hline Work well done & $.134(.016)^{* * *}$ & $.134(.016)^{* * *}$ & $.250(.023) * * *$ & $.250(.024) * * *$ \\
\hline Useful work & $.057(.017) * *$ & $.057(.017)^{* *}$ & $.148(.025) * * *$ & $.147(.025)^{* * *}$ \\
\hline Value alignment & $.112(.039)^{* *}$ & $.111(.039)^{* *}$ & $.163(.058) * *$ & $.161(.059) * *$ \\
\hline Change in working conditions & $039(.056)$ & $.037(.056)$ & $-.058(.083)$ & $-.055(.083)$ \\
\hline Change in working conditions $*$ Value alignment & $.020(.013)$ & $.021(.013)$ & $.042(.019)^{*}$ & $.042(.019)^{*}$ \\
\hline Western countries & $-.035(.175)$ & $-.034(.126)$ & $-.001(.247)$ & $-.182(.168)$ \\
\hline Change in working conditions $*$ Western countries & $-.038(.054)$ & - & $.012(.079)$ & - \\
\hline $\begin{array}{l}\text { Change in working conditions * Value alignment } * \\
\text { Western countries }\end{array}$ & - & $-.009(.008)$ & - & $-.013(.012)$ \\
\hline Country Level Intercept & $2.095(.212) * * *$ & $2.099(.212) * * *$ & $.889(.313) * *$ & $.916(.312) * *$ \\
\hline Log likelihood & $-3,079.664$ & $-3,079.237$ & $-4,330.249$ & $-4,329.709$ \\
\hline $\mathrm{N}$ & 3,199 & 3,199 & 3,199 & 3,199 \\
\hline
\end{tabular}

Notes: Hierarchical linear model regression coefficients with standard errors in parentheses.

$* * * \mathrm{p}<.001 ; * * \mathrm{p}<.01 ; * \mathrm{p} \leq .05$ 


\section{Online Appendix}

Table A5. Regression for Job Satisfaction \& Motivation with the interaction effect of Autonomy

\begin{tabular}{|c|c|c|c|c|}
\hline Predictor & \multicolumn{2}{|c|}{ Job satisfaction } & \multicolumn{2}{|c|}{ Motivation } \\
\hline Gender & $-.026(.024)$ & $-.026(.024)$ & $.112(.036)^{* *}$ & $.116(.036)^{* *}$ \\
\hline Age & $-.003(.001)^{*}$ & $-.003(.001)^{*}$ & $-.001(.002)$ & $-.001(.002)$ \\
\hline Education & $.007(.010)$ & $.007(.010)$ & $-.021(.014)$ & $-.021(.014)$ \\
\hline Income & $.000(.000)$ & $.000(.000)$ & $.000(.000)$ & $.000(.000)$ \\
\hline Size of workplace & $.008(.007)$ & $.008(.007)$ & $-.017(.011)$ & $-.017(.011)$ \\
\hline Tenure & $-.000(.001)$ & $-.000(.001)$ & $-.004(.002)$ & $-.004(.002)$ \\
\hline Working hours & $-.003(.001)^{*}$ & $-.003(.001)^{*}$ & $.001(.002)$ & $.001(.002)$ \\
\hline Work pressure & $-.042(.007) * * *$ & $-.042(.007) * * *$ & $-.014(.011)$ & $-.014(.011)$ \\
\hline Autonomy & $-.055(.041)$ & $-.055(.041)$ & $.024(.061)$ & $.024(.061)$ \\
\hline Organizational involvement & $-.095(.012) * * *$ & $-.095(.012) * * *$ & $.205(.018)^{* * *}$ & $.205(.018)^{* * *}$ \\
\hline Work well done & $.135(.016) * * *$ & $.135(.016) * * *$ & $.250(.024) * * *$ & $.250(.024) * * *$ \\
\hline Useful work & $.057(.017)^{* *}$ & $.057(.017) * *$ & $.147(.025)^{* * *}$ & $.147(.025)^{* * *}$ \\
\hline Value alignment & $.110(.040)^{* *}$ & $.110(.040)^{* *}$ & $.042(.015)^{* *}$ & $.164(.060)^{* *}$ \\
\hline Change in working conditions & $.020(.063)$ & $.101(.063)$ & $.123(.049)^{*}$ & $-.048(.094)^{*}$ \\
\hline Change in working conditions $*$ Autonomy & $-.0 .30(.013)^{*}$ & $-.0 .30(.013)^{*}$ & $-.005(.020)$ & $-.005(.020)$ \\
\hline Change in working conditions $*$ Value alignment & & $.020(.013)$ & & $.041(.019)^{*}$ \\
\hline Country Level Intercept & $2.288(.227)^{* * *}$ & $2.288(.227) * * *$ & $1.416(.239) * * *$ & $.910(.336)^{* *}$ \\
\hline Log likelihood & $-3,077.737$ & $-3,077.736$ & $-4,332.594$ & $-4,330.311$ \\
\hline $\mathrm{N}$ & 3,199 & 3,199 & 3,199 & 3,199 \\
\hline
\end{tabular}

Notes: Hierarchical linear model regression coefficients with standard errors in parentheses.

$* * * \mathrm{p}<.001 ; * * \mathrm{p}<.01 ; * \mathrm{p}<.05$ 
Table A6. Regression for Job Satisfaction \& Motivation with the interaction effect of Job security

\begin{tabular}{|c|c|c|c|c|}
\hline Predictor & \multicolumn{2}{|c|}{ Job satisfaction } & \multicolumn{2}{|c|}{ Motivation } \\
\hline Gender & -.045 & -.043 & $0.115 * *$ & $.119 * *$ \\
\hline Age & $-.003 *$ & $-.003 *$ & -0.001 & -.001 \\
\hline Education & .001 & .001 & $-0.029 *$ & -.029 \\
\hline Income & .000 & .000 & 0.000 & $.000 * *$ \\
\hline Size of workplace & .001 & .001 & -0.017 & -.018 \\
\hline Tenure & -.001 & -.001 & $-0.005 *$ & $-.005^{*}$ \\
\hline Working hours & $-.004 * *$ & $-.004 * *$ & 0.001 & .001 \\
\hline Work pressure & $-.035 * * *$ & $-.035 * * *$ & $-0.009 *$ & -.010 \\
\hline Autonomy & $.036 * *$ & $.036 * *$ & 0.036 & $.036^{*}$ \\
\hline Job security & -.052 & -.050 & -0.050 & -.045 \\
\hline Organizational involvement & $.089^{* * *}$ & $.089 * * *$ & $0.201 * * *$ & $.200 * * *$ \\
\hline Work well done & $.130^{* * *}$ & $.129 * * *$ & $0.242 * * *$ & $.241 * * *$ \\
\hline Useful work & $.044 * *$ & $.044 * *$ & $0.138 * * *$ & $.138^{* * *}$ \\
\hline Value alignment & $.052 * * *$ & $.103 *$ & $0.051 * *$ & $.176^{* *}$ \\
\hline Change in working conditions & $.103^{* *}$ & .017 & $0.113^{*}$ & -.066 \\
\hline Change in working conditions $*$ Job security & .002 & .029 & -0.005 & -.003 \\
\hline Change in working conditions $*$ Value alignment & & .003 & & $.043 *$ \\
\hline Country Level Intercept & $2.625 * * *$ & $2.409 * * *$ & $1.539 * * *$ & $1.011^{* * *}$ \\
\hline Log likelihood & $-2,887.059$ & $-2,886.196$ & $-4,133.539$ & $-4,131.267$ \\
\hline $\mathrm{N}$ & 3,053 & 3,053 & 3,057 & 3,057 \\
\hline
\end{tabular}

Notes: Hierarchical linear model regression coefficients with standard errors in parentheses.

$* * * \mathrm{p}<.001 ; * * \mathrm{p}<.01 ; * \mathrm{p}<.05$ 
Table A7. Regression for Job Satisfaction \& Motivation with 2009-2010 country changes in per capita incomes

\begin{tabular}{lcc}
\hline \hline Predictor & Job satisfaction & Motivation \\
Gender & $-.026(.024)$ & $0.117(.036)^{* *}$ \\
Age & $-.003(.001)^{*}$ & $-0.001(.002)$ \\
Education & $.007(.010)$ & $-0.021(.014)$ \\
Income & $.000(.000)$ & $0.000(.000)$ \\
Size of workplace & $.008(.007)$ & $-0.017(.011)$ \\
Tenure & $.000(.001)$ & $-0.004(.002)$ \\
Working hours & $-.003(.001)^{*}$ & $0.001(.002)$ \\
Work pressure & $-.042(.007)^{* * *}$ & $-0.014(.011)$ \\
Autonomy & $.034(.011)^{* *}$ & $0.036(.016)^{*}$ \\
Organizational involvement & $.096(.012)^{* * *}$ & $0.205(.018)^{* * *}$ \\
Work well done & $.134(.016)^{* * *}$ & $0.250(.024)^{* * *}$ \\
Useful work & $.058(.017)^{* *}$ & $0.148(.025)^{* * *}$ \\
Value alignment & $.112(.040)^{* *}$ & $0.165(.059)^{* *}$ \\
Change in working conditions & $.036(.056)$ & $-0.059(.083)$ \\
Change in working conditions $*$ Value alignment & $.020(.013)$ & $0.042(.019)^{*}$ \\
2009-2010 changes in per capita incomes & $.000(.011)$ & $0.007(.018)$ \\
Country Level Intercept & $2.097(.213)^{* * *}$ & $0.862(.013)^{* *}$ \\
Log likelihood & $-3,080.270$ & $-4,330.332$ \\
$\mathrm{~N}$ & 3,199 & 3,199 \\
\hline
\end{tabular}

Notes: Hierarchical linear model regression coefficients with standard errors in parentheses.

$* * * \mathrm{p}<.001 ; * * \mathrm{p}<.01 ; * \mathrm{p}<.05$ 